\title{
Experimental and Numerical Study of At-Rest Lateral Earth Pressure of Overconsolidated Sand
}

\author{
Magdi El-Emam \\ Department of Civil Engineering, American University of Sharjah, P.O. Box 26666, Sharjah, UAE \\ Correspondence should be addressed to Magdi El-Emam, melemam@aus.edu \\ Received 1 April 2011; Accepted 6 June 2011 \\ Academic Editor: Devendra Narain Singh \\ Copyright () 2011 Magdi El-Emam. This is an open access article distributed under the Creative Commons Attribution License, \\ which permits unrestricted use, distribution, and reproduction in any medium, provided the original work is properly cited.
}

\begin{abstract}
The paper presents a one-meter-height rigid facing panel, supported rigidly at the top and bottom to simulate nonyielding retaining wall system. A set of load cells is used to measure the horizontal force at the top and bottom of the facing panel, which is converted to equivalent horizontal earth pressure acting at the back of the wall. Another set of load cells is used to measure the vertical load at the bottom of the wall facing, both at the toe and the heel. Uniformly graded sand was used as backfill soil. The measured wall responses were used to calibrate a numerical model that used to predict additional wall parameters. Results indicated that the measured horizontal earth force is about three times the value calculated by classical at-rest earth pressure theory. In addition, the location of the resultant earth force is located closer to $0.4 \mathrm{H}$, which is higher compared to the theoretical value of $\mathrm{H} / 3$. The numerical model developed was able to predict the earth pressure distribution over the wall height. Test set up, instrumentation, soil properties, different measured responses, and numerical model procedures and results are presented together with the implication of the current results to the practical work.
\end{abstract}

\section{Introduction}

Earth pressure distribution behind retaining wall systems is a soil-structure interaction problem. Therefore, determination of earth pressure distribution at the back of the wall should be done interactively with the deflection of the wall. However, this is not the case in the current design practice. Practically, the hydrostatic earth pressure distribution behind the wall is adopted according to the at-rest, active, or passive earth pressure theories for both internal and external stability analyses. Furthermore, triangular distribution is typically assumed for of the lateral earth pressure for at-rest, active or passive conditions. This assumption can be true for walls that are free to move laterally or rotate around the toe with sufficient movement to initiate the sliding wedge (i.e., active or passive state). However, this is not the case for nonyielding walls that do not develop the limiting static active or passive earth pressure, because the movements are not sufficient to fully mobilize the backfill soil shear strength. Typically, all underground basements walls, tunnels, bridge abutments, culverts, and piles are examples of nonyielding structures that are in contact with soil. These structures usually undergo relatively very small movement which is insufficient to initiate the sliding wedge behind the wall and to relieve the pressure to its active or passive state. Examples of nonyielding walls are schematically shown in Figure 1. Compaction-induced earth pressure and the resulting stresses and deformations can be of serious concern in the design and analysis of these structures.

This paper presents experimental and numerical models developed to study the vibratory compaction-induced lateral stresses acting against vertical nondeflecting walls. The experimental model provided reliable quantitative results for values of earth pressure at rest $\left(K_{o}\right)$. Tests are conducted using the shaking table facility at the Royal Military College of Canada (RMCC). It should be emphasized that the stresses studied in this paper are static types only. In other words, the shaking table was not excited dynamically during the measurement of stresses mobilized behind the wall. The table was dynamically excited, however, to achieve the maximum density during construction stage to study the mobilization of at-rest stresses behind nonyielding walls. 


\section{Literature Review}

Using the so-called "local arching" effect of the soil, Terzaghi [1] explained the parabolic distribution of earth pressure behind relatively flexible wall supported at two ends (Figure 1). Geotechnical practitioners have traditionally calculated the at-rest earth pressure coefficient, $K_{o}$ against nonyielding walls using the 60 years old Jaky's formula [2], which simplified in a widely accepted form as

$$
K_{o}=1-\sin \phi^{\prime}
$$

where $\phi^{\prime}$ is the effective angle of internal friction of the soil. The measured values of $K_{o}$ observed in normally consolidated deposits seem to agree well with the simplified Jaky's equation (i.e., (1)), as reported by Schmidt [3], Sherif et al. [4], Al-Hussaini [5], and Mayne and Kulhawy [6]. Therefore, (1) is practically accepted as the horizontal-tovertical stress ratio in loose sand and normally consolidated soil Sherif et al. [7]. When the backfill behind the wall is subjected to compaction effort or vibration, the magnitude of at-rest stresses is expected to increase beyond values calculated with (1).

Coefficient of earth pressure at rest, $K_{o}$, in soil mass is influenced by various factors, particularly the previous stress history of the retained soil, which is represented by the overconsolidation ratio (OCR). Schnaid and Houlsby [8] reported values of $K_{o}$ in the range between 1 and 2 for overconsolidated deposits. Worth [9] proposed empirical relationship to calculate the coefficient of earth pressure at rest for overconsolidated sand as follows:

$$
K_{o}=\left(1-\sin \phi^{\prime}\right) \mathrm{OCR}-\left\{\frac{\mu}{1-\mu}\right\}(\mathrm{OCR}-1) .
$$

In (2), Poisson's ratio $\mu=0.1$ to 0.3 for loose sand; and $\mu=0.3$ to 0.4 for dense sand. Mayne and Kulhawy [6] provide a summary of the effects of stress history on $K_{o}$, including data compiled from over 170 different soils tested and reported by many researchers. They conduct a statistical analysis of this data and determine relationships between atrest earth pressure and soil stress history. Based on these results, Jaky's formula was found to have close agreement with the data for normally consolidated soil and deviated significantly for overconsolidated soil. Mayne and Kulhawy [6] provided a relationship between $K_{o}$ and OCR that builds on Jaky's simplified formula as follows:

$$
K_{o}=\left(1-\sin \phi^{\prime}\right) \mathrm{OCR}^{\sin \phi^{\prime}} .
$$

Cherubini et al. [10] found that values of $K_{o}$, calculated using (3), are 3.5\% less than the average measured values, which is practically acceptable. Hanna and Al-Romhein [11] compared the theoretical values predicted by Worth [9] and Mayne and Kulhawy [6] with experimental results conducted on well-graded dry silica sand. The comparison indicated that Mayne and Kulhawy's formula provided good agreement with the experimental results of the coefficient of earth pressure at rest $K_{o}$ up to OCR $=3.0$, whereas the theoretical values underestimated $K_{o}$ thereafter. The theoretical values

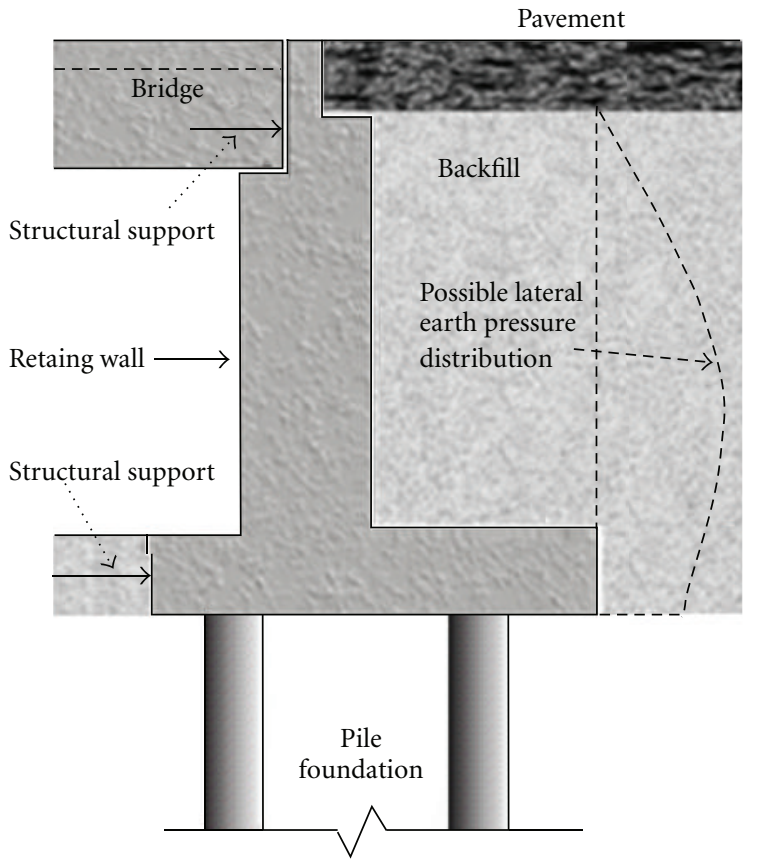

(a) Bridge abutment

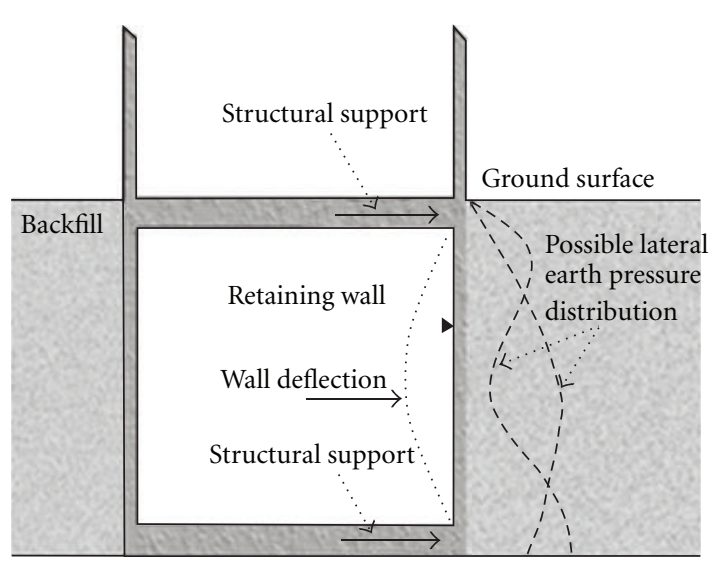

(b) Building basement

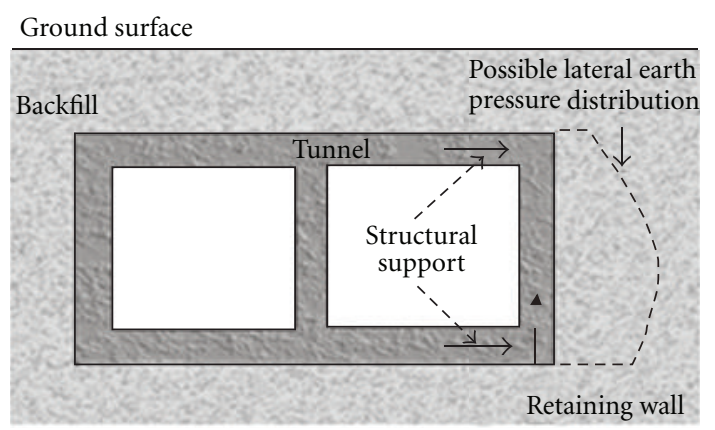

(c) Underground tunnel system

FIGURE 1: Schematic views of structures with nonyielding retaining walls. 


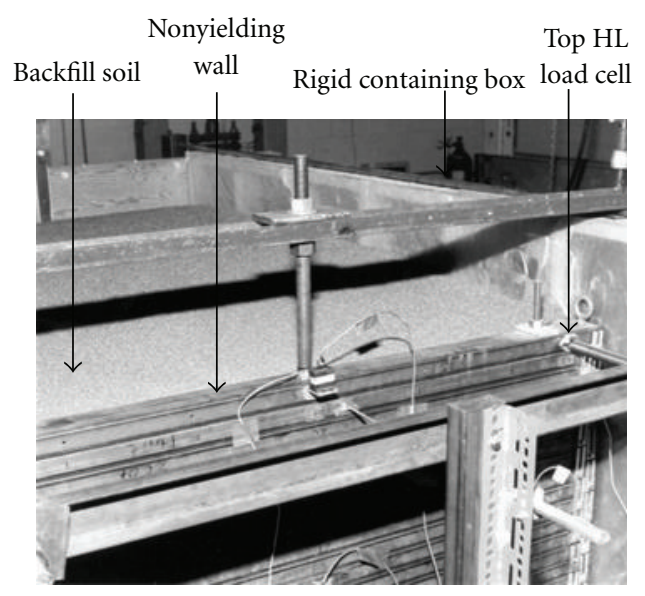

(a) Top instrumentation

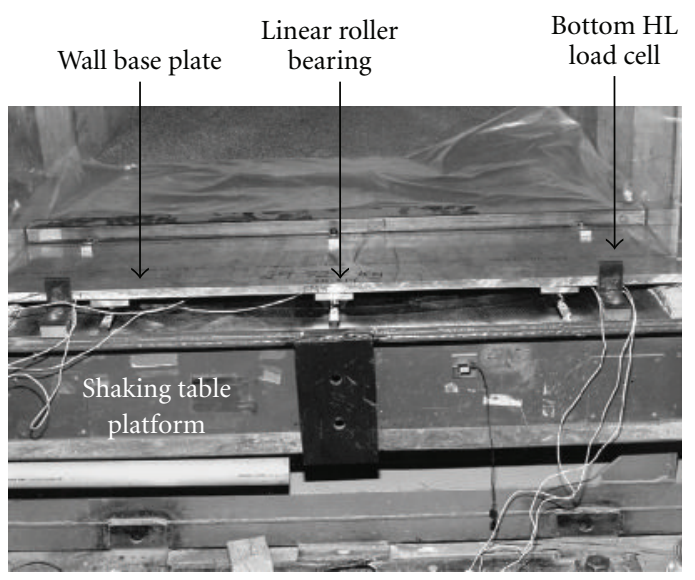

(b) Bottom instrumentation

FIGURE 2: Typical experimental model and instrumentations on nonyielding wall on RMC shaking table.

of Worth [9] were about $10 \%$ to $15 \%$ higher than the experimental values for OCR $<3.0$, whereas it were $10 \%$ to $12 \%$ lower thereafter.

Despite its practical significance and attractive simplicity, Jaky's formula and its derivative (i.e., (1) and (3)) claim the dependence of $K_{o}$ only on the soil internal friction angle, $\phi^{\prime}$. However, Feda [12] proved theoretically that $K_{o}$ depends on soil deformation. The ignorance of soil deformation in calculating $K_{o}$ using Jaky's formula is considered a major deficiency, as stated by Feda [12]. Therefore, in order to come out with a more representative formula, analysis must include the effect of the overconsolidation resulting from the compaction and the deformation of soil-wall system.

An important aspect of vibratory compaction, which is not generally appreciated, is the increase of the lateral stresses in the soil due to vibratory compaction. Sand backfills are usually normally consolidated prior to compaction with earth pressure coefficient $\left(K_{o}\right)$, approximately equal to values calculated with (1). Investigations by Schmertmann [13], Leonards and Frost [14], and Massarsch [15, 16] have shown that subsequent compaction resulted in a significant increase of the horizontal stress in soil. Furthermore, laterally constrained densification of normally consolidated sand by vibration under an effective overburden pressure was found to increase the coefficient of earth pressure at-rest [6]. Peck and Mesri [17] evaluated theoretically the compactioninduced earth pressure. They found out that the lateral earth pressure near the backfill surface was closer to the passive conditions, whereas in the lower part, it was related to normally consolidated at-rest conditions. Experimental measurements by Massarsch and Fellenius [18], using CPT, concluded that the lateral earth pressure increases significantly as a result of vibratory compaction. Duncan and Seed [19] stated that the compaction of soil against nonyielding structures can significantly increase the near-surface residual lateral pressures to greater than at-rest values. However, lateral pressures are generally smaller at depths below backfill surface, which apparently as a result of structural deflections. They concluded that horizontal stress can exceed the vertical stress if a soil deposit is heavily compacted. In fact, Sherif et al. [7] concluded that horizontal stresses developed during compaction usually looked-in and do not disappear when compaction effort removed. This conclusion was confirmed by Duncan and Seed [19] who stated that about $40 \%$ to $90 \%$ of the lateral earth pressure induced during compaction may remain as residual pressures. In previously compacted soils (soils with previously "locked-in" compaction stresses), additional compaction resulted in a smaller increases in earth pressures during compaction than in uncompacted soils, and a negligible fraction of these increases may be retained as residual earth pressure upon the completion of compaction [20].

Quantitative studies of the at-rest earth pressure distribution behind rigid retaining walls have been conducted by Mackey and Kirk [21], Sherif et al. [7], Fang and Ishibashi [22], and Fang et al. [23], using reduced-scale model tests. Clough and Duncan [24], Seed and Duncan [25], and Matsuzawa and Hazarika [26] used the finite element method (FEM) to investigate the earth pressure distribution on nonyielding walls. Despite these extensive earlier studies, there still remain conflicting points regarding the magnitude and distribution of static stresses exerted against nonyielding retaining walls. In addition, little information has been reported regarding the variation of stress condition in the soil mass during the filling and compaction process. Also, the controversy over the point of application of the total static thrust exerted against retaining walls has not been yet resolved. This study is, therefore, undertaken to clarify and resolve the foregoing unknowns. An experimental investigation of the at-rest earth pressure of overconsolidated cohesionless soil acting on perfectly supported retaining walls was conducted. A scaled walls model with vertical rigid facing, retaining horizontal backfill, was developed in the laboratory. The model was instrumented to measure the horizontal and vertical reactions at the top and bottom of the facing panel; see Figure 2. The total earth force acting on the wall at different wall heights, and its point of application were deduced from the measured forces. Tests were conducted 


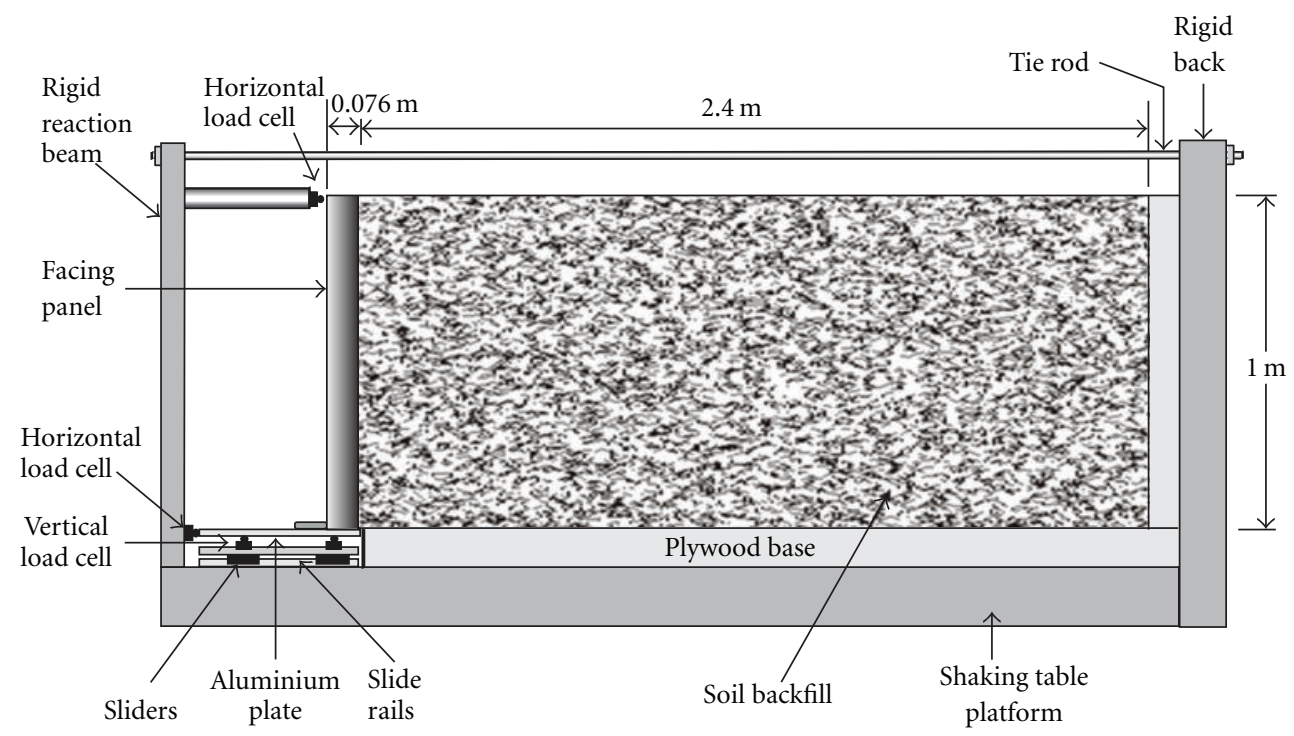

FIGURE 3: Experimental model setup, arrangement, and instrumentations.

on walls retaining homogeneous overconsolidated dense sandy soil, compacted by vibration. Results measured in the experimental model have been used to verify a numerical model that simulates a nonyielding wall supporting over consolidated cohesionless soil.

\section{Experimental Tests}

A set of $1 / 3$ scale model tests were carried out at the Royal Military College of Canada using the shaking table test facility. The physical models were $1 \mathrm{~m}$ high $(\mathrm{H}), 1.4 \mathrm{~m}$ wide, $(\mathrm{W})$ and $2.4 \mathrm{~m}$ depth (D), as shown in Figure 3. The $1 \mathrm{~m}$ high model wall tested in this study is representing a $3 \mathrm{~m}$ height prototype wall with $1 / 3$ scale factor. The models comprised a very stiff facing panel rigidly attached to the shaking table platform $(2.7 \mathrm{~m} \times 2.7 \mathrm{~m}$ in plan area). The wall and retained soil mass were contained in a rigid strong box affixed to the table platform (Figure 2). The soil extended $2.4 \mathrm{~m}$ from the back of the facing panel to the back of containing box.

The total horizontal force transmitted to the rigid facing panel wall was measured by load cells attached to the rigid reaction beam used to restrain the facing panel in the horizontal direction (Figures 2 and 3). The wall footing support comprised frictionless linear bearings to decouple horizontal and vertical wall forces [27, 28]. Vertical and horizontal load cells were installed at the base of the facing panel to measure the forces transmitted to the footing (facing toe). A potentiometer-type displacement transducer located at mid-elevation of the wall facing was connected to record lateral deflection of the facing panel. Details of the experimental design and test configurations can be found in El-Emam and Bathurst [27]. The strong box side walls are constructed with $6 \mathrm{~mm}$-thick Perspex covered on the inside with two layers of transparent polyethylene sheeting to minimize side wall friction.

Artificial silica-free synthetic olivine sand was used as retained soil. The soil properties are summarized in Table 1 .
TABLE 1: Backfill sandy soil properties.

\begin{tabular}{lcc}
\hline Soil property & $\begin{array}{c}\text { From direct } \\
\text { shear tests }\end{array}$ & $\begin{array}{c}\text { Back-calculated } \\
\text { from direct shear } \\
\text { box test simulations } \\
\text { using FLAC }\end{array}$ \\
\hline Bulk unit weight $\left(\mathrm{kN} / \mathrm{m}^{3}\right)$ & 15.7 & - \\
Peak friction angle & $51^{\circ}$ & $58^{\circ}$ \\
Residual friction angle, $\phi_{\mathrm{cv}}$ & $46^{\circ}$ & $46^{\circ}$ \\
Dilation angle, $\Psi$ & $15^{\circ}$ & $15^{\circ}$ \\
Cohesion, $c(\mathrm{kPa})$ & 0 & 0 \\
Shear modulus $(\mathrm{MPa})$ & - & 7 \\
Bulk modulus $(\mathrm{MPa})$ & - & 6 \\
\hline
\end{tabular}

All tests in the current investigation were performed with the same soil volume and placement technique. The soil was placed in 8 thin lifts, and each lift is $0.125 \mathrm{~m}$ height and compacted by lightly shaking each lift using the shaking table. To bring the sand lift to its dense state, the shaking table box was vibrated at frequency of $6 \mathrm{~Hz}$ for 5 seconds. Load cells readings were recorded after compaction of each individual lift. These processes were repeated until the model wall is fully constructed up to $1 \mathrm{~m}$ height. Once the model was fully constructed, it was shaken twice using the same compaction effort (i.e., frequency of $6 \mathrm{~Hz}$ for 5 seconds) in order to study the effect of repeated vibration on the mobilized at-rest earth pressure on nonyielding walls.

\section{Numerical Model}

The numerical simulations were carried out using the program FLAC [29]. The FLAC numerical grid for the simulation of the nonyielding wall tests is shown in Figure 4. In all tests, the height of each model and the backfill width were kept at $1 \mathrm{~m}$ and $2.4 \mathrm{~m}$, respectively. The thickness of the wall-facing panel was taken as $76 \mathrm{~mm}$ to match the physical 


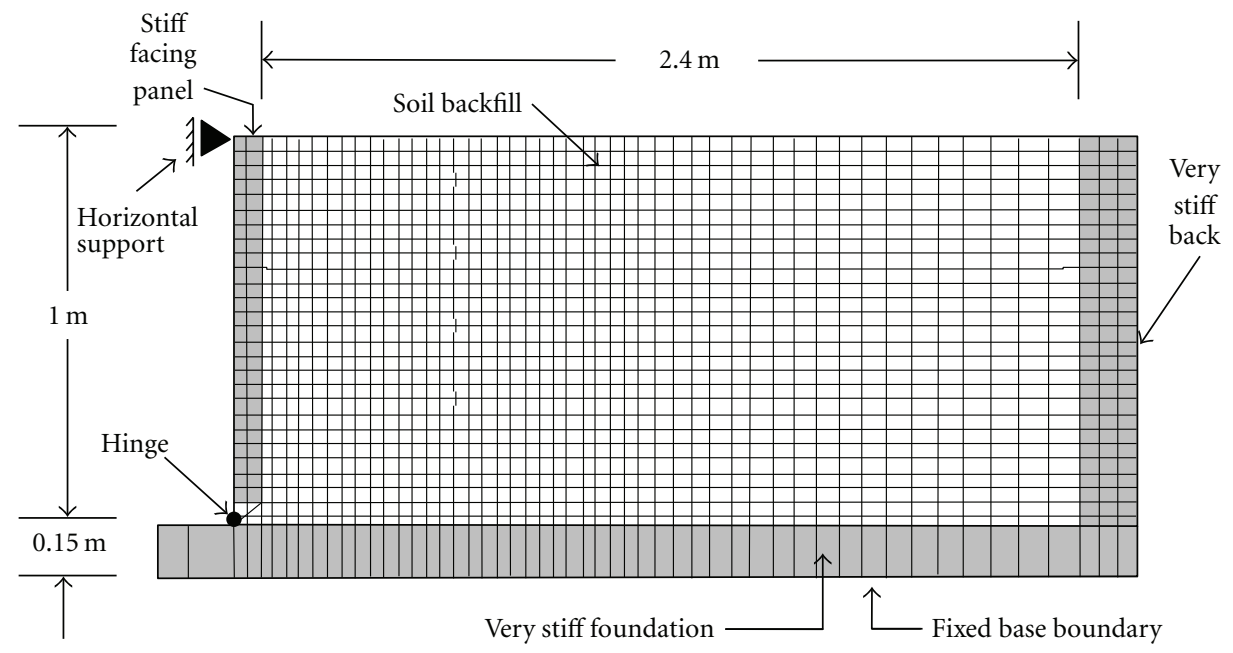

FIGURE 4: FLAC numerical model of nonyielding wall retaining sand backfill.

tests. The backfill soil was modeled as a purely frictional, elastic-plastic material with Mohr-Coulomb failure criterion. This model allows elastic behaviour up to yield (MohrCoulomb yield point defined by the friction angle) and plastic flow after yield under constant stress. The soil model is described by constant values of shear and bulk elastic modulus for preyield behavior. Results of direct shear box tests on specimens of the same sand material have been reported by El-Emam and Bathurst $[27,28,30]$ and are summarized in Table 1 . They also carried out numerical simulations of the direct shear tests using FLAC code to back calculate the "true" peak plane strain friction angle of the soil and modulus values. The peak plane strain friction angle from the shear box simulations was $\phi_{\mathrm{PS}}=58^{\circ}$, which is consistent with the value predicted using the equation by Bolton [31] to convert the peak friction angle deduced from conventional direct shear box tests to the true plane strain friction angle of the soil. The high direct shear friction angle and, therefore, high plane strain friction angle is mainly due to the angularity of the soil particles. The electronic microscopic photograph for the sand used in this study showed that the sand particles are sharp angular to subangular in shape. Soil properties for the backfill sand used in the numerical analyses are summarized in Table 1.

A no-slip boundary at the bottom of the sand backfill was assumed to simulate the rough boundary in the physical tests (i.e., a layer of sand was glued to the bottom of the shaking table containing box). The vertical boundary at the right side of the model was designed as rigid wall to simulate the back wall of the strong box in the shaking table tests. The model wall facing toe boundary condition was modelled with twonoded one-dimensional beam elements with three plastic hinges (Figure 4). Four-noded, linear elastic continuum zones were used to model the full height-rigid-facing panel, shaking table, and far-end boundary. The facing thickness was $76 \mathrm{~mm}$, as used in physical models, with a united weight of $17.24 \mathrm{kN} / \mathrm{m}^{3}$ and linear elastic material properties. The material parameters adopted for the facing elements values are shear modulus, $G_{w}=1000 \mathrm{Mpa}$, bulk modulus, $K_{w}=1100 \mathrm{Mpa}$, and unlimited failure stress. These specific values of shear and bulk modulus were chosen to ensure high rigidity of the facing panel.

The interface between the backfill soil and the facing panel was modelled using a thin ( $15 \mathrm{~mm}$ thick) soil column directly behind the facing panel (Figure 4). The soil-facing panel interface material properties were the same as the backfill properties except for the friction angle $(\phi)$. This value was computed from measured toe loads in the physical test wall according to

$$
\delta=\tan ^{-1}\left(\frac{R_{V i}-W_{f}}{R_{H i}}\right) .
$$

Here, $R_{V i}$ and $R_{H i}$ are the measured vertical and horizontal force acting at the facing panel at different backfill height $H_{i}$, respectively, and $W_{f}$ is the weight of the facing panel. The average back-calculated values of the interface friction angle was $\delta=0$. However, average value of $\delta=2^{\circ}$ was used to maintain numerical stability. Experimental results by El-Mhaidib [32] showed that the interface friction angle between smooth steel and uniformly graded sand could be as maximum as $\delta=2^{\circ}$ for the level of normal stress applied in the current study. It should be noted that the numerical grid was constructed in layers to simulate soil placement in the physical model.

\section{Experimental Results}

Directions and locations of forces used for static earth pressure analysis are shown in Figure 5(a). For each backfill height, $H_{i}$, both front and backward vertical loads, $R_{\mathrm{VFi}}$ and $R_{\mathrm{VBi}}$, are directly measured. In addition, the top and the bottom horizontal loads, $R_{\mathrm{HBi}}$ and $R_{\mathrm{HTi}}$, are also measured 


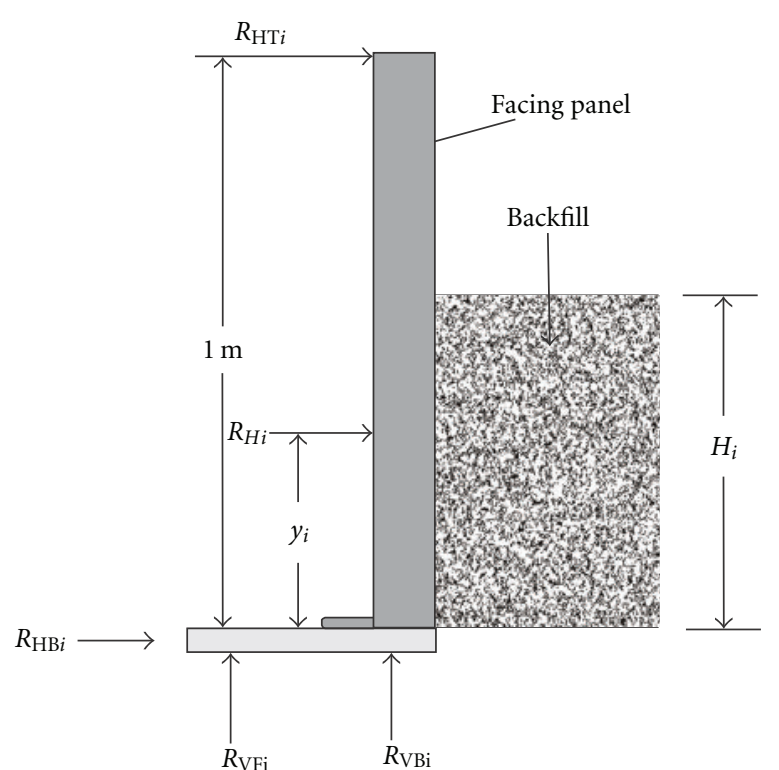

(a) Experimental

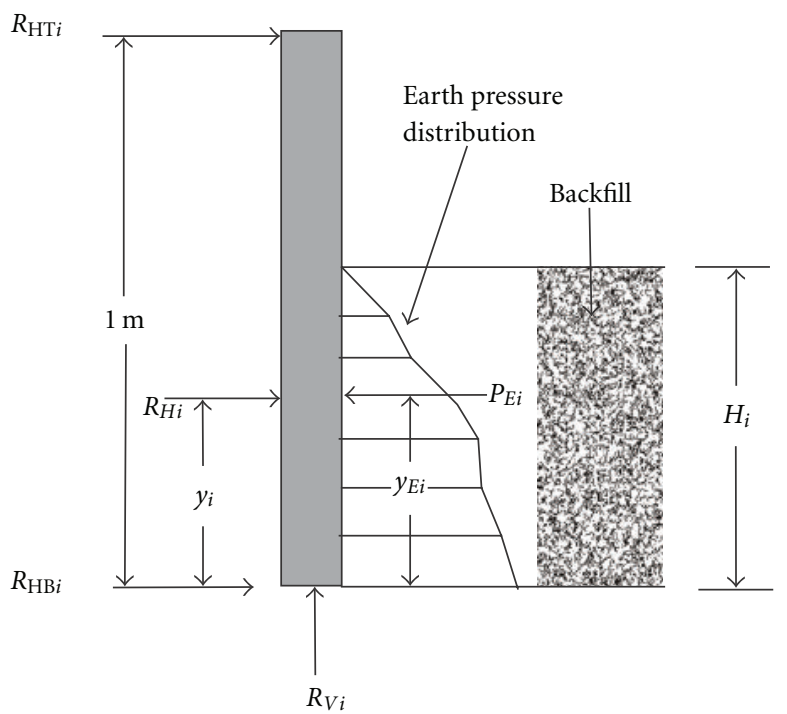

(b) Numerical

FIGURE 5: Force diagram used for the analysis of construction stages in both experimental and numerical models.

using load cells. The total lateral earth force, $R_{H i}$, and its point of application, $y_{i}$, are calculated from

$$
\begin{gathered}
R_{H i}=R_{\mathrm{HTi}}+R_{\mathrm{HBi}}, \\
y_{i}=\frac{R_{\mathrm{HTi}}}{R_{\mathrm{Hi}}} .
\end{gathered}
$$

Figure 6(a) shows the variation of the horizontal load measured at the top and bottom of the facing panel, $R_{\mathrm{HTi}}$ and $R_{\mathrm{HBi}}$, with backfill height, $H_{i}$, at different construction stages. As expected, the horizontal force measured at the bottom of the facing panel is larger compared to the horizontal force measured at the top. In addition, both measured values are nonlinearly increased with the backfill height, $H_{i}$. Shown also in Figure 6(a) is the total horizontal force measured at the facing panel, $R_{H}$, which is equivalent to the at-rest total lateral earth force applied at the back of the facing panel. According to Figure 6(a), the total earth force at the back of the facing panel, $R_{H i}$, calculated according to (5), increased nonlinearly as the backfill height increased. Variation of the vertical toe load with backfill height at different construction stages is shown in Figure 6(b) for the tested model wall. The magnitude of the vertical toe load, $R_{V i}$, was generally equal to the self-weight of the facing panel, $W_{f}$, for all construction stages. This results indicated that the facing panel is perfectly smooth, and therefore, a zero down-drag force is developed between the backfill soil and the facing panel. A slight reduction in the measured vertical load, $R_{V}$, was noticed compared to the facing panel-self weight, for wall heights larger than $0.8 \mathrm{~m}$. This may be attributed to the uplift force developed due to the soil over densification with larger height. Finally, the value of the front vertical force, $R_{\mathrm{VF}}$, is significantly smaller compared to the value of the vertical force measured at the back of the base plate, $R_{\mathrm{VB}}$. Taken together, the data in Figure 6(b) lead to the conclusion that for smooth and vertical nonyielding walls, the vertical load developed at the footing is generally equal to the self-weight of the facing panel, $W_{f}$.

The elevation of the resultant lateral earth force above the foundation of nonyielding wall, normalized to the backfill height is shown in Figure 6(c). The resultant elevation, $y_{i}$, is an indication of the distribution of the lateral earth pressure over the backfill height, $H_{i}$. The current theory of practice assumes a triangular distribution for at-rest earth pressure over the backfill height. Therefore, the design methodology usually assumes that the point of application of at-rest lateral earth force located at one third of the backfill height (i.e., $y_{i}=H_{i} / 3$ ), above the wall foundation. Results shown in Figure 6(c) indicated that the resultant earth force is located approximately at $0.4 H_{i}$, for different backfill height. This is clear indication that the distribution of the at-rest lateral earth pressure is deviated from the theoretically assumed triangular shape. In this context, Terzaghi [1] reported that the distribution of the at-rest lateral earth pressure is closer to parabolic shape, with zero value at the backfill surface. Distribution of the at-rest earth pressure is studied using the numerical model developed and verified in the current study.

Figure 7 represents the theoretical values of the lateral earth pressure at rest, $P_{o}$, that is calculated with

$$
P_{o}=\frac{1}{2} K_{o} \gamma H_{i}^{2}
$$

In (7), the unit weight of the backfill soil, $\gamma=15.7 \mathrm{kN} / \mathrm{m}^{3}$, $H_{i}$, is the backfill height (Figure 5) and $K_{o}$ is the at-rest earth pressure coefficient calculated according to (3) with $\phi^{\prime}=51^{\circ}$. It should be noted that values of $K_{o}$ calculated with (1) and (3) are similar for normally consolidated sand (i.e., OCR = 1). Equations (3) and (7) are used together to calculate the variation of the at-rest lateral 


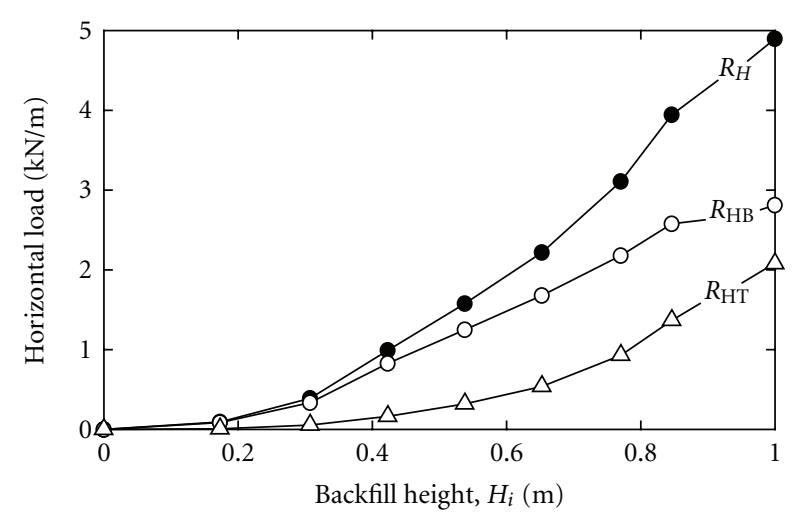

(a) Horizontal load

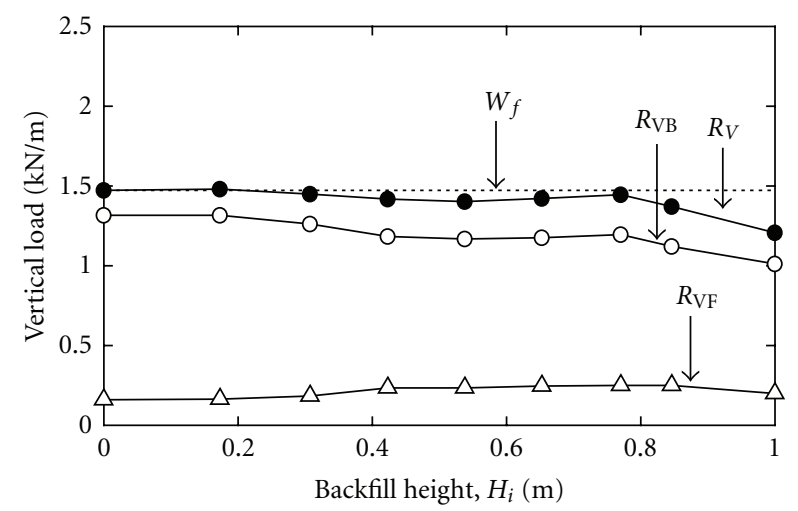

(b) Vertical load

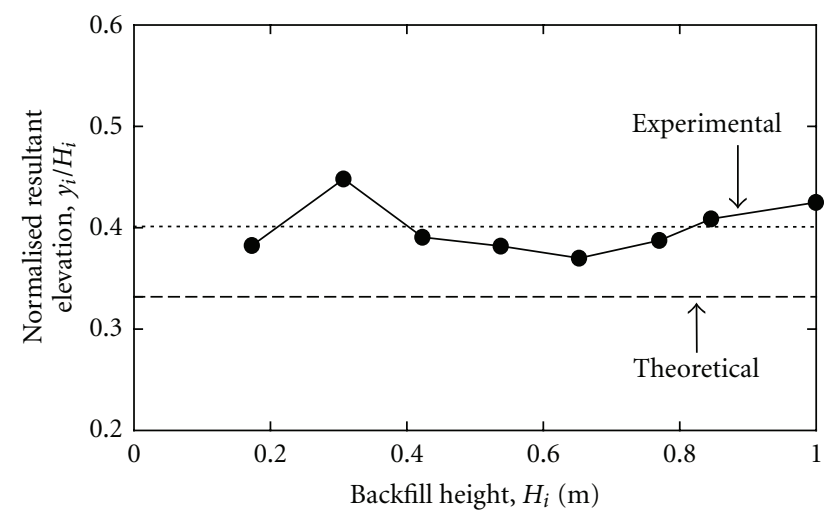

(c) Resultant elevation

Figure 6: Variation of horizontal toe load, vertical toe load, and normalized earth pressure resultant elevation with the backfill height during construction stages.

earth force, $P_{o}$ with the backfill height, $H_{i}$, at different overconsolidation ratio, OCR. Plotted also in Figure 7 are values of the at-rest earth force, $R_{H i}$ that deduced from the measured horizontal toe load at different backfill height. The variation of both measured and calculated at-rest earth forces with backfill height showed similar trends at different overconsolidation ratio. Moreover, for the sandy soil and the vibration compaction procedures used in this study, the measured value of at-rest earth force is in perfect agreement with the calculated value for sandy soil with OCR $=4$.

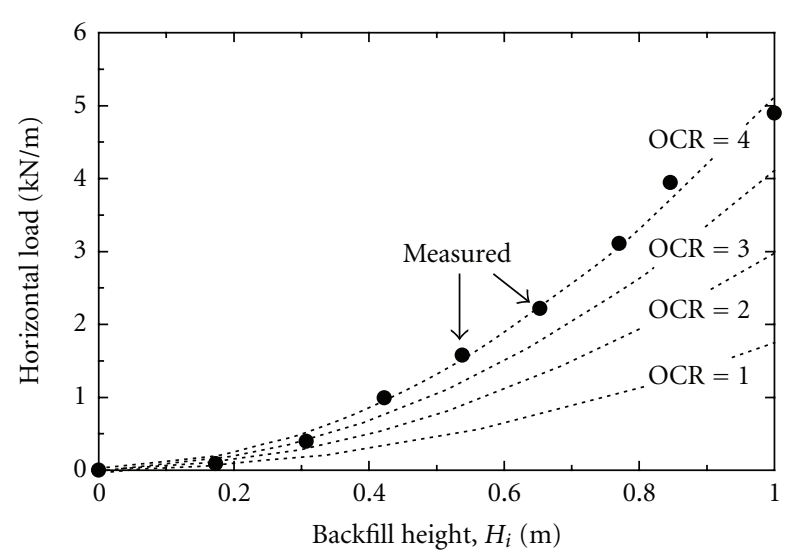

FIGURE 7: Variation of horizontal earth force with the backfill height during construction stages at different overconsolidation ratio.

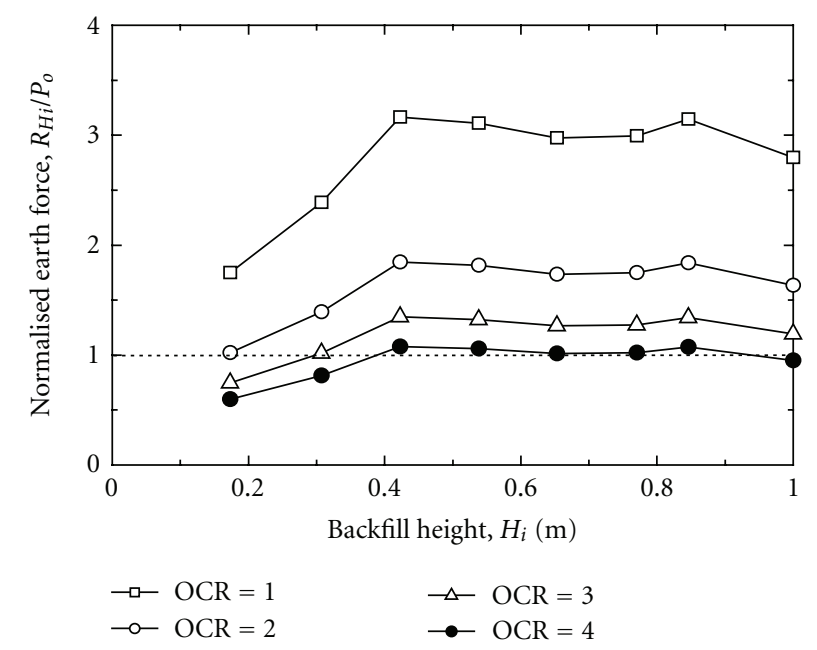

FIGURE 8: Variation of horizontal earth force, normalized to the theoretical calculated value, with the backfill height, at different overconsolidation ratio.

This perfect agreement is clearer for backfill height larger than $0.4 \mathrm{~m}$, which is attributed to the more densification of sand with larger heights. Results reported in Figure 7 clearly concluded that the old Jaky's formula (i.e., (1), [2]) is largely underestimating the at-rest earth pressure coefficient for overconsolidated sand (i.e., OCR $>1$ ). However, the equation suggested by Mayne and Kulhawy [6], (i.e., (2)) can be used to predict the values of at-rest lateral earth pressure coefficient, provided that the overconsolidation ratio is determined accurately.

Figure 8 presents the lateral earth force measured at the back of the facing panel normalised to the calculated lateral earth force. Equations (3) and (7) are used to calculate the lateral earth forces at different backfill height and different overconsolidation ratio. The figure indicated that the traditional Jaky's formula is underestimating the lateral earth force by more than $60 \%$ of the measured value. As 


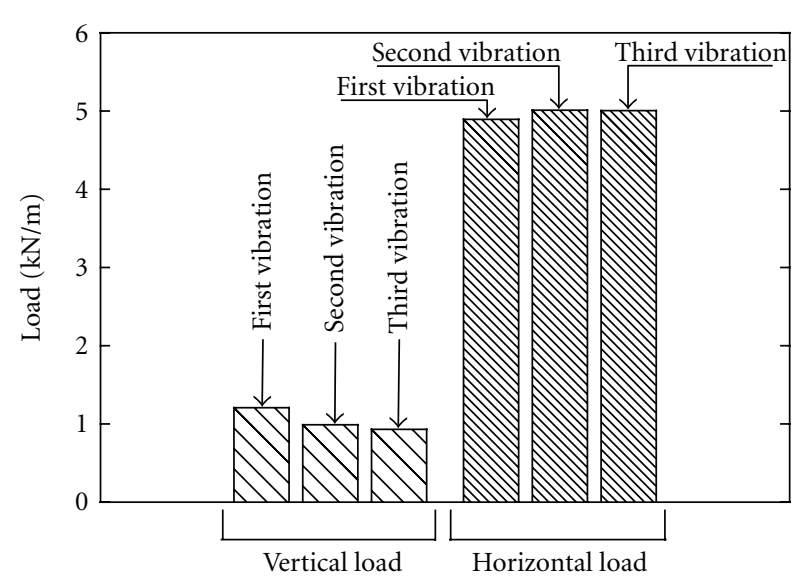

FIgURE 9: Effect of second and third vibration on the measured vertical and horizontal earth forces on nonyielding wall.

the sand overconsolidation ratio increased, the normalized earth force ratio, $R_{H i} / P_{o}$, decreased. At overconsolidated ratio $\mathrm{OCR}=4$, the normalized earth force ratio is getting closer to unity, which indicates a perfect agreement between the measured and calculated earth forces. In conclusion, the overconsolidation ratio of sandy soil is an important parameter in determining the static lateral earth force developed against nonyielding walls.

The construction of the model wall was finalized with the compaction of the last soil lift using the vibration procedures used previously with all soil lifts. Results presented in this paper were measured after the model was vibrated for the compaction of last soil lift. This is considered the first time when the model is fully vibrated (i.e., end of construction vibration). It was decided to vibrate the model wall two times in addition to the first time in order to report the effect of further vibrations on the resulted wall response. Figure 9 presents the measured vertical and horizontal earth force after each time the model wall was vibrated. It is clear that further vibration of the model wall has insignificant effect in both lateral earth force and its point of application. This is may be due to the higher overconsolidation ratio the sand backfill reached under repeated vibration during construction stages (i.e., OCR $=4$ ). This higher OCR is an indication of the higher density of the sand. Therefore, further compaction beyond this density produced a little value of lateral earth force. Figure 9 also indicated that the vertical force at the bottom of the wall was slightly reduced with more vibration. This is attributed to the slight uplift force developed between the sand and the facing panel. This force was measured experimentally by a load cell attached at the top of the facing panel (Figure 2(a)).

\section{Comparison between Predictions and Measured Responses}

Calibration of the numerical model was focused on achieving a good agreement between the calculated and measured horizontal wall force at top and bottom, vertical force, and the location of the lateral earth force resultant at different

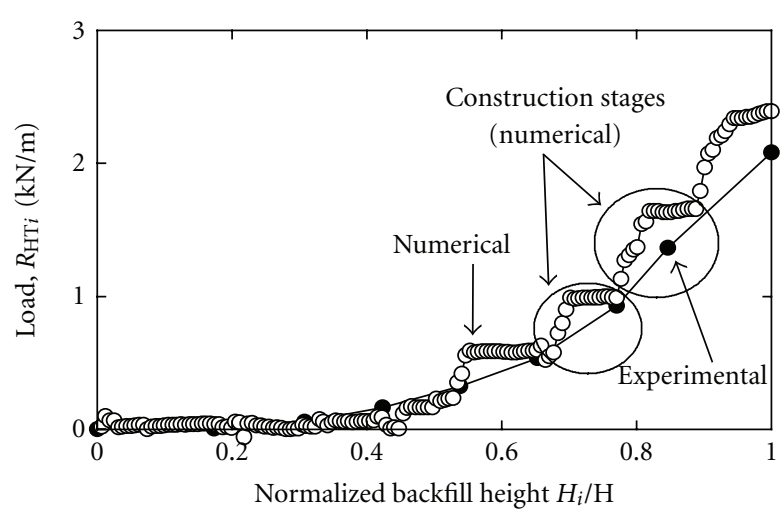

(a) Top horizontal load

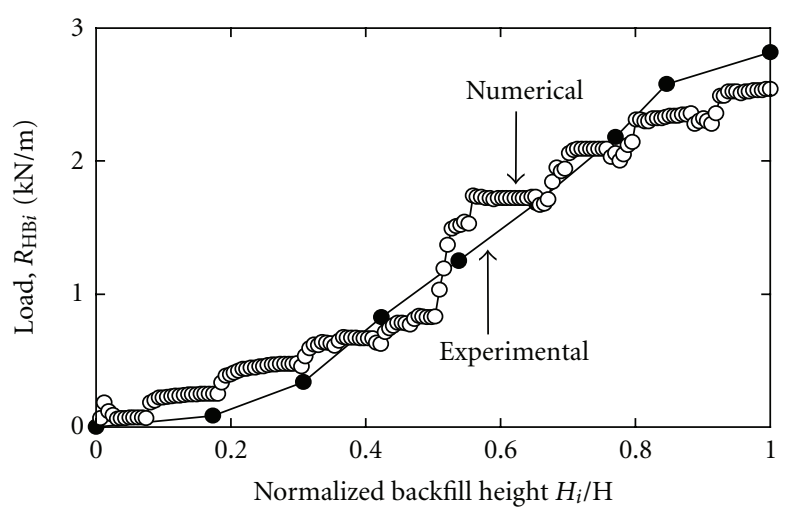

(b) Bottom horizontal load

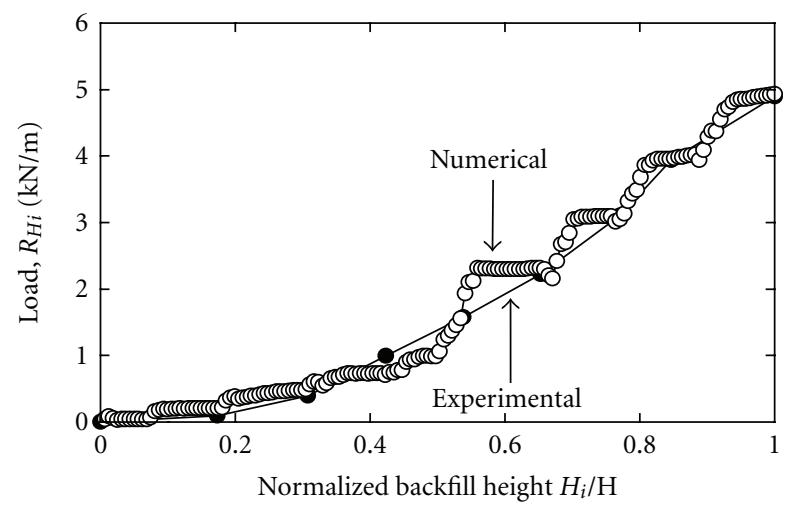

(c) Total horizontal load

FIGURE 10: Predicted and measured horizontal load versus backfill height during construction stages.

construction stages. It should be noted that the soil backfill in experimental model was constructed in 8 layers, which is replicated in the numerical model. During the construction of the numerical model, there were two options that could be used alternatively in order to compact each sand layer. The first option is to vibrate each layer using the prespecified horizontal motion that used in the experimental model. This method was found to be time consuming, and the final construction of the model took about 24 hours to execute in a personal computer. Alternatively, after the placement of each sand layer, a horizontal stress condition equivalent to $K_{o}$ 


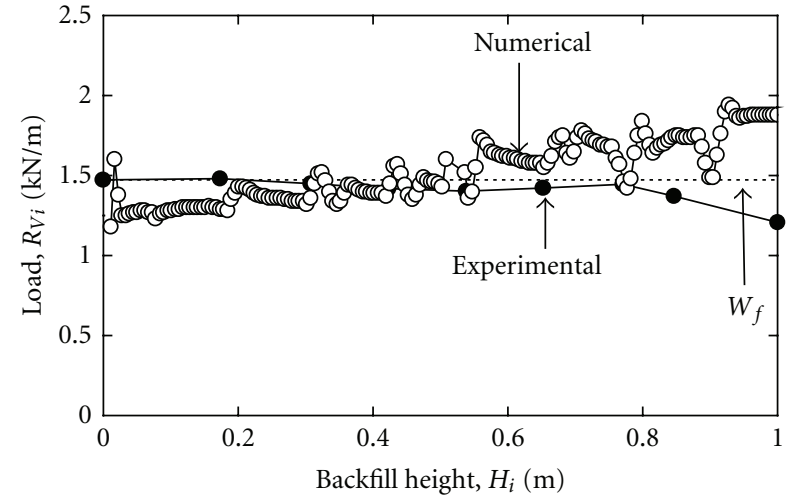

(a) Vertical load

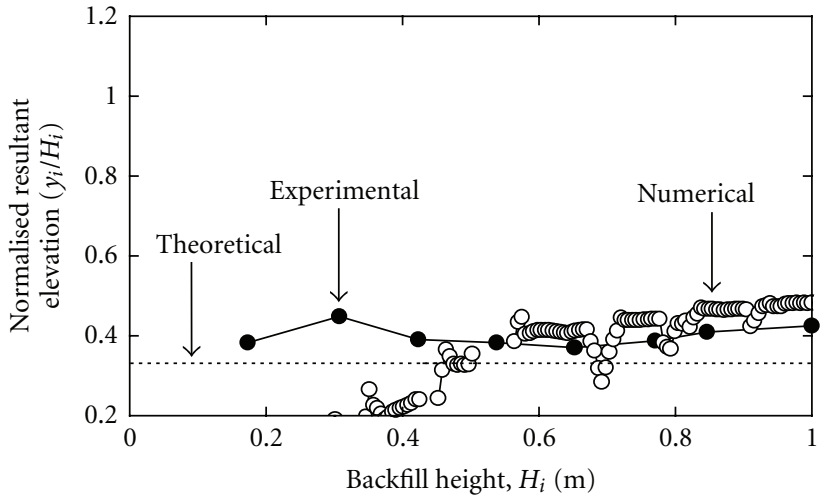

(b) Resultant elevation

FIGURE 11: Predicted and measured vertical toe load and normalized resultant elevation versus backfill height during construction stages.

is applied for this layer, and the model is taken to equilibrium under this stress condition before placing the next sand layer. This method was used successfully by Seed and Duncan [25] in modeling static compaction of $2 \mathrm{~m}$-height nonyielding wall. $K_{o}$ is the at-rest earth pressure coefficient calculated using (3), with soil properties reported in Table 1.

6.1. Total Forces Acting on the Wall and Resultant Elevation. Figure 10 provides a summary of top, bottom, and total horizontal wall forces versus backfill height for both physical and numerical experiments conducted in this study. Figure 11(a) shows both measured and numerical values of vertical load at the footing of the wall. While Figure 11(b) shows the measured and predicted resultant elevation above the wall footing normalized to the backfill height. Shown also in Figure 11 are the weight of the wall facing $\left(W_{f}\right)$ and the theoretical resultant elevation $\left(y_{i}\right)$ for comparison. It should be noted that each point of the experimental results presented in Figures 10 and 11 is representing the measured response at the end of construction of each sand layer (i.e., sand placement and compaction). However, the numerical results showed both stages for each soil lift (see Figure 10(a)). Results presented in both Figures 10 and 11 indicate good qualitative and quantitative agreement between FLAC calculated total wall forces and the experimental results. It can be noticed that there are slight over prediction and underprediction in both top and bottom horizontal loads, respectively, for backfill height closer to $1 \mathrm{~m}$. However, the total horizontal force at the wall facing is well predicted at different backfill heights, as shown in Figure 10(c). Figure 11(a) shows that both predicted and measured vertical load at the footing of the wall are closer to the wall facing own weight $\left(W_{f}\right)$. Also, both measured and predicted values of the horizontal forces resultant elevation are in good agreement, indicating resultant elevation larger than the theoretically assumed value (i.e., $\mathrm{H} / 3$ ).

Values of horizontal forces shown in Figure 10 are numerically recorded at the wall top and bottom to simulate the experimental setup and results. In addition, the lateral earth pressure at rest is recorded numerically at different locations of the wall back and at different backfill height. The recorded values of lateral earth pressure are used to back calculate the horizontal earth forces $\left(P_{E i}\right)$ and its vertical location from the bottom of the wall $\left(y_{E i}\right)$. Figure 5(b) shows the definition of both $P_{E i}$ and $y_{E i}$. Back calculated earth pressure resultant and its location above the footing are shown in Figure 12, together with the experimentally measured values. Shown also in Figure 12 are values of lateral earth forces and its location above the wall toe predicted using (3) and (7). It should be noted that the numerical earth pressure value for each backfill height is calculated as the average earth pressure values during the placement of the soil layer and during compaction stage. Figure 12(a) shows great agreement between measured, numerical, and theoretical predicted values of lateral earth force at the back of the wall. A slight underprediction of the earth force can be noticed at backfill height equal to $0.6 \mathrm{~m}$. The reason for this underprediction is not clear to the author. Both numerical and experimental values of the resultant elevation are in good agreement for backfill heights larger than $0.5 \mathrm{~m}$ (Figure 12(b)). In addition, oth numerical and experimental values indicated that the earth pressure resultant elevation is larger than $0.33 \mathrm{H}$, which is assumed by theoretical methods. It should be noted that the numerical model slightly underpredicted the resultant elevation compared to the experimental model, for backfill height smaller than $0.5 \mathrm{~m}$. This may be due to the perfect bond assumed between the backfill soil and the foundation base.

6.2. Earth Pressure Distribution. The earth pressure distributions on the wall at different backfill heights are shown in Figure 13. Also shown in this figure are the theoretical at-rest earth pressure distributions calculated using Jacky's formula (i.e., OCR = 1) and Mayne and Kulhawy equation with $\mathrm{OCR}=4$. In addition to that, the passive earth pressure distribution is plotted in Figures 13(c)-13(f). It can be seen that the earth pressure distribution is a triangular in shape for smaller backfill height (i.e., $H_{i}<0.5 \mathrm{~m}$ ), Figures 12(a) and $12(\mathrm{~b})$. As the backfill height increased above $0.5 \mathrm{~m}$, the distribution is not a hydrostatic type. Results presented in Figure 13 show that an extrahorizontal earth pressure larger than that theoretically predicted by Jack's formula is 


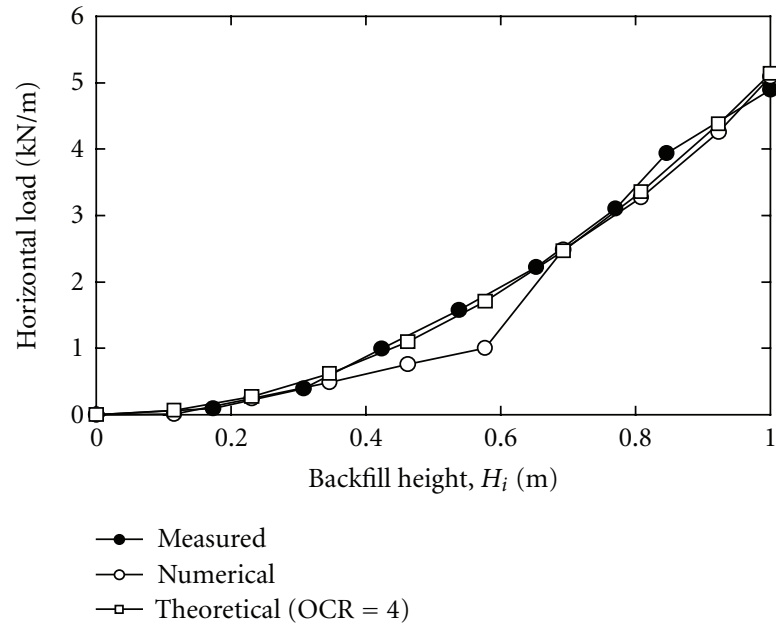

(a) Earth pressure resultant

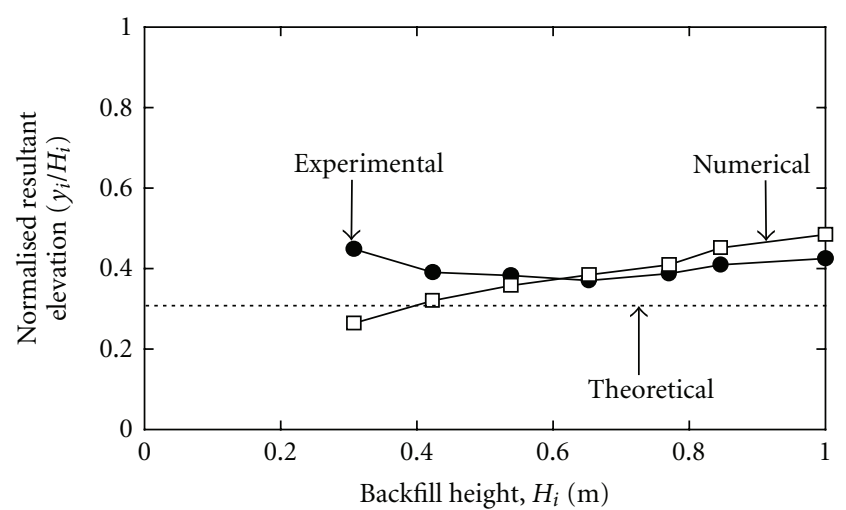

(b) Resultant elevation

FIGURE 12: Experimental, numerical, and theoretical predicted lateral earth pressure resultant and point of application versus backfill height.

induced by compaction. It is interesting to note that the lateral earth pressure distribution predicted near the top of the backfill was closer to the passive earth pressure estimated with Rankine theory, especially for larger backfill heights. As the backfill height increases beyond $0.5 \mathrm{~m}$, the earth pressure significantly increases at the top of the backfill compared to the bottom, due to compaction effort. These results are in good agreement with the experimental results of Chen and Fang [33], which showed higher earth pressure at the top of vibratory compacted model wall compared to the bottom. It can be concluded that the distribution of earth pressure resulted from overconsolidated sand on nonyielding walls is not hydrostatic nor following the traditional jacky's formula.

\section{Conclusion and Recommendations}

The current study presents experimental and numerical investigation of at-rest lateral earth pressure resulted due to overconsolidated sandy soil adjacent to nonyielding walls. For this purpose, scaled model walls were constructed and specially instrumented to measure the lateral earth force. The sandy soil was compacted by vibration in order to increase the overconsolidation ratio. In addition, a numerical model has been developed to simulate nonyielding wall and validated using the measured wall responses. Based on the results presented in this study, the following points could be summarized.

(1) For nonyielding wall systems with nearly smooth back, the vertical load transfer to the footing of the wall is approximately equivalent to the facing self weight. This value expected to be larger in cases of walls with rough back.

(2) Overconsolidation ratio of sandy soil increases with repeated vibration compaction, and as a result, the horizontal effective stress increases significantly.
(3) Jaky's formula is proven to significantly underestimate the at-rest lateral earth pressure coefficient for overconsolidated sand.

(4) Overconsolidation ratio of sandy soil is an important factor that affects the at-rest lateral earth force. Including a suitable overconsolidation ratio in the modified Jaky's formula produced realistic at-rest earth pressure coefficient.

(5) The resultant of at-rest lateral earth pressure is measured to be located closer to $0.4 \mathrm{H}$ ( $\mathrm{H}$ is the backfill height), from the footing of the wall, which is above the $0.3 \mathrm{H}$ assumed by the classical earth pressure theory.

(6) The location of the earth pressure resultant measured in the current study indicated that the hydrostatic distribution for at-rest condition assumed by the classical earth pressure theories is not valid for overconsolidated sand.

(7) The numerical model developed in this study predicts wall responses that agree well with the measured responses.

(8) The earth pressure distribution predicted numerically shows that the increase of the earth pressure due to vibration at the wall top is more significant compared to the wall bottom.

\section{Acknowledgments}

The author is grateful for funding provided by the office of research and graduate studies, American University of Sharjah, UAE (Travel Grant, FRG11-III-14). The many discussions with Dr. Kianoosh Hatami, University of Oklahoma, and Dr. Richard Bathurst, Royal Military College of Canada (RMC), on the numerical and experimental models are also gratefully acknowledged. 


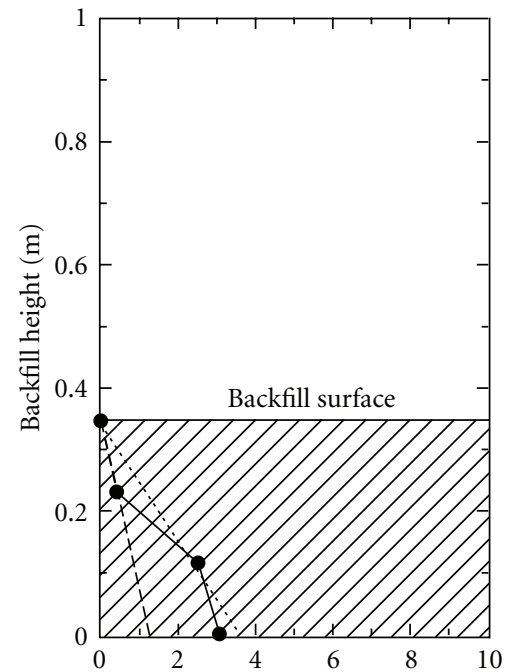

(a) $H=0.35 \mathrm{~m}$

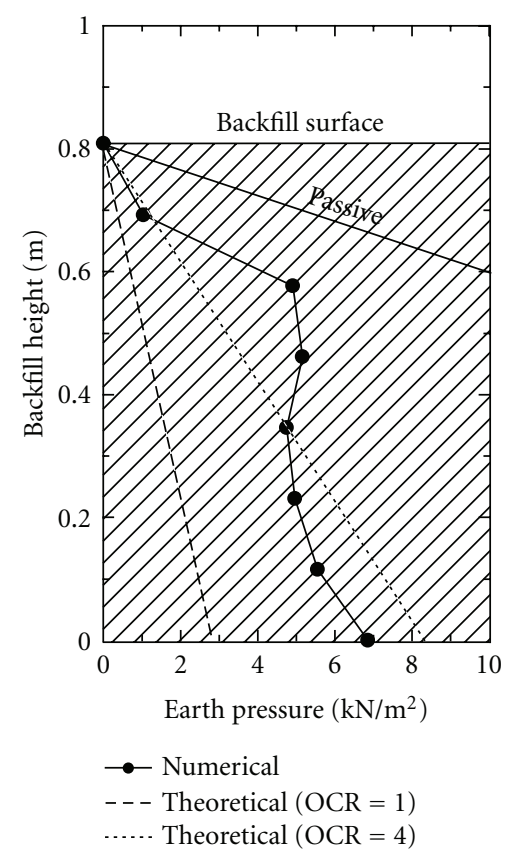

(d) $H=0.8 \mathrm{~m}$

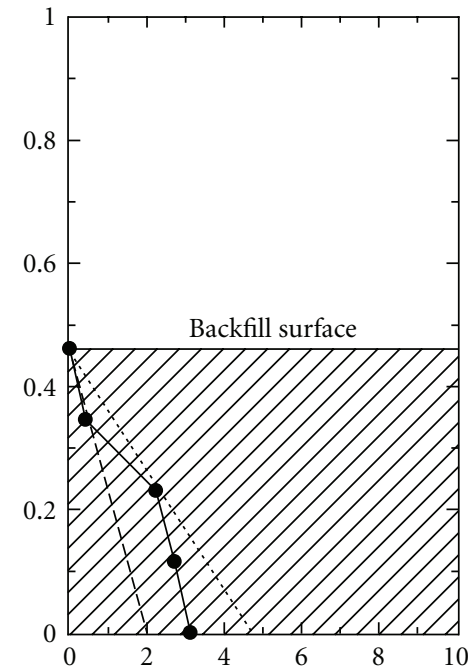

(b) $H=0.46 \mathrm{~m}$

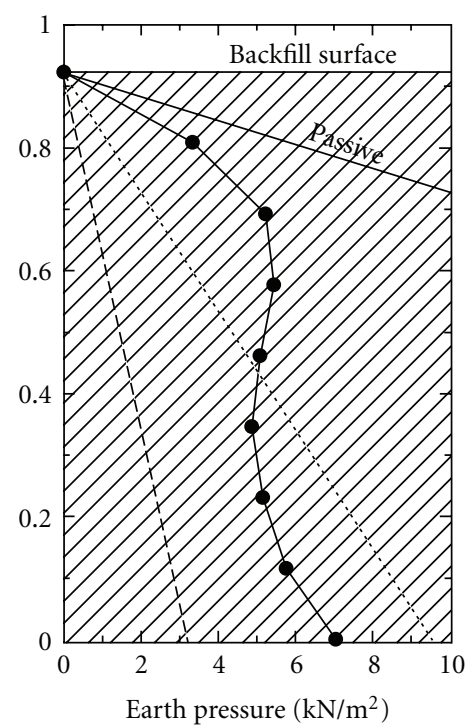

$-\bullet$ Numerical
--- Theoretical $(\mathrm{OCR}=1)$
$\ldots \ldots$ Theoretical $(\mathrm{OCR}=4)$

(e) $H=0.9 \mathrm{~m}$

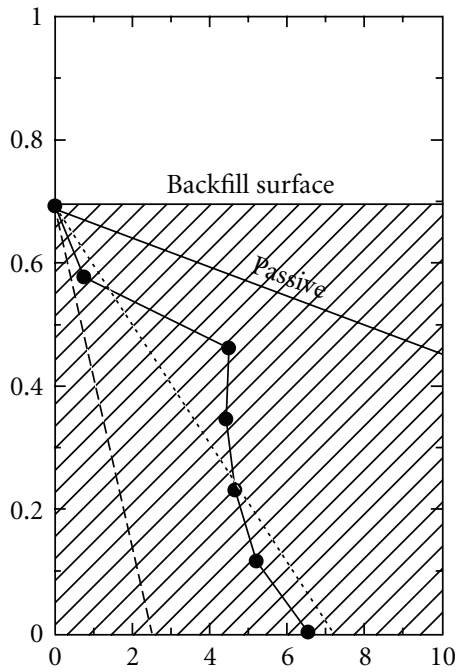

(c) $H=0.69 \mathrm{~m}$

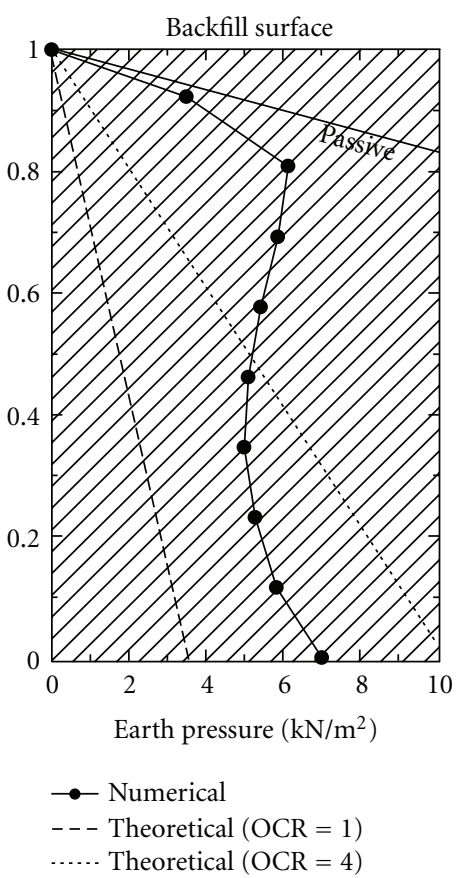

(f) $H=1.0 \mathrm{~m}$

FIGURE 13: Numerical and theoretical prediction of lateral earth pressure distribution versus backfill height during construction stages.

\section{References}

[1] K. Terzaghi, "General wedge theory of earth pressure," ASCE Transaction, vol. 106, pp. 68-80, 1941.

[2] J. Jaky, "The coefficient of earth pressure at-rest," Journal of Society of Hungarian Architects and Engineers, pp. 355-358, 1944 (Hungarian).

[3] B. Schmidt, "Discussion paper-Earth pressure at rest related to stress history," Canadian Geotechnical Journal, vol. 3, no. 4, pp. 239-242, 1966.

[4] M. A. Sherif, I. Ishibashi, and D. E. Ryden, "Coefficient of lateral earth pressure at rest in cohesionless soil," Soil Eng. Research Report 10, University of Washington, 1974.
[5] M. Al-Hussaini, "Comparison of various methods for determining $\mathrm{K}_{\mathrm{o}}$," in Proceedings of the Symposium of Laboratory Shear Strength of Soil, pp. 78-93, ASTM, University of Florida, 1980.

[6] P. W. Mayne and F. H. Kulhawy, " $\mathrm{K}_{\mathrm{o}}-\mathrm{OCR}$ relationships in soil," Journal of the Geotechnical Engineering Division, vol. 108, no. 6, pp. 851-872, 1982.

[7] M. A. Sherif, Y. S. Fang, and R. I. Sherif, " $K_{a}$ and $K_{o}$ behind rotating and non-yielding walls," Journal of Geotechnical Engineering, vol. 110, no. 1, pp. 41-56, 1984.

[8] F. Schnaid and G. T. Houlsby, "Measurement of the properties of sand by the cohesion pressuremeter test," Soil Mechanics Report 113/91, University of Oxford, 1991. 
[9] C. P. Worth, "General theories of earth pressure and deformation," in Proceedings of the 5th European Conference on Soil Mechanics and Foundation Engineering, vol. 2, pp. 33-52, Madrid, Spain, 1972.

[10] C. Cherubini, C. I. Giasi, and F. M. Guadagno, "The coefficient of pressure at rest of Subapennine Blue Clays in Matera (Southern Italy)," in Proceedings of the 6th International Congress of the International Association of Engineering Geology, D. G. Price and A. A. Balkema, Eds., vol. 2, pp. 1163-1169, Amsterdam, 1990.

[11] A. Hanna and R. Al-Romhein, "At-rest earth pressure of overconsolidated cohesionless soil," Journal of Geotechnical and Geoenvironmental Engineering, vol. 134, no. 3, pp. 408-412, 2008.

[12] J. Feda, " $\mathrm{K}_{\mathrm{o}}$ coefficient of sand in triaxial apparatus," Journal of Geotechnical Engineering, vol. 110, no. 4, pp. 519-524, 1984.

[13] J. H. Schmertmann, "Measure and use of the in-situ lateral stress," in The Practice of Foundation Engineering, A Volume Honoring Jorj O. Osterberg, R. J. Krizek, C. H. Dowding, and F. Somogyi, Eds., pp. 189-213, Department of Civil Engineering, Technological Institute, Northwestern University, Evanston, Ill, USA, 1985.

[14] G. A. Leonards and J. D. Frost, "Settlement of shallow foundations on granular soils," Journal of Geotechnical Engineering, vol. 114, no. 7, pp. 791-809, 1988.

[15] K. R. Massarsch, "Deep soil compaction using vibratory probes," in Proceedings of the ASTM Symposium on Design, Construction, and Testing of Deep Foundation Improvement: Stone Columns and Related Techniques, R. C. Bachus, Ed., pp. 297-319, ASTM Special Technical Publication, STP 1089, London, UK, 1991.

[16] K. R. Massarsch, "Settlement analysis of compacted fill," in Proceedings of the 13th International Conference on Soil Mechanics and Foundation Engineering (ICSMFE '94), vol. 1, pp. 325-328, New Delhi, India, 1994.

[17] R. B. Peck and G. Mesri, "Discussion of compaction-induced earth pressure under $\mathrm{K}_{\mathrm{o}}$-condition," Journal of Geotechnical Engineering, vol. 113, no. 11, pp. 1406-1408, 1987.

[18] K. R. Massarsch and B. H. Fellenius, "Vibratory compaction of coarse-grained soils," Canadian Geotechnical Journal, vol. 39, no. 3, pp. 695-709, 2002.

[19] J. M. Duncan and R. B. Seed, "Compaction-induced earth pressure under $\mathrm{K}_{\mathrm{o}}$-condition," Journal of Geotechnical Engineering, vol. 112, no. 1, pp. 1-22, 1986.

[20] S. E. Rehnman and B. B. Broms, "Lateral pressure on basement wall: results from full-scale tests," in Proceedings of the 5th European Conference on Soil Mechanics and Foundation Engineering, vol. 1, pp. 189-197, 1972.

[21] R. D. Mackey and D. P. Kirk, "At rest, active and passive earth pressures," in Proceedings of the South East Asian Conference on Soil Mechanics and Foundation Engineering, pp. 187-199, Bangkok, Thailand, 1967.

[22] Y. S. Fang and I. Ishibashi, "Static earth pressures with various wall movements," Journal of Geotechnical Engineering, vol. 112, no. 3, pp. 317-333, 1986.

[23] Y. S. Fang, J. M. Chen, and C. Y. Chen, "Earth pressures with sloping backfill," Journal of Geotechnical and Geoenvironmental Engineering, vol. 123, no. 3, pp. 250-259, 1997.

[24] G. W. Clough and J. M. Duncan, "Finite element analysis of retaining wall behavior," Journal of the Soil Mechanics and Foundations Division, vol. 97, no. SM12, pp. 1657-1673, 1971.
[25] R. B. Seed and J. M. Duncan, "FE analysis: compactioninduced stresses and deformations," Journal of Geotechnical Engineering, vol. 112, no. 1, pp. 22-43, 1986.

[26] H. Matsuzawa and H. Hazarika, "Analyses of active earth pressure against rigid retaining wall subjected to different modes of movement," Soils and Foundations, vol. 36, no. 3, pp. 51-65, 1996.

[27] M. El-Emam and R. J. Bathurst, "Experimental design, instrumentation and interpretation of reinforced soil wall response using a shaking table," International Journal of Physical Modeling in Geotechnics, vol. 4, no. 4, pp. 13-32, 2004.

[28] M. M. El-Emam and R. J. Bathurst, "Facing contribution to seismic response of reduced-scale reinforced soil walls," Geosynthetics International, vol. 12, no. 5, pp. 215-238, 2005.

[29] Itasca Consulting Group, FLAC: Fast Lagrangian Analysis of Continua. Version 4, Itasca Consulting Group, Minneapolis, Minn, USA, 2000.

[30] M. M. El-Emam and R. J. Bathurst, "Influence of reinforcement parameters on the seismic response of reduced-scale reinforced soil retaining walls," Geotextiles and Geomembranes, vol. 25, no. 1, pp. 33-49, 2007.

[31] M. D. Bolton, "The strength and dilatancy of sands," Géotechnique, vol. 36, no. 1, pp. 65-78, 1986.

[32] A. I. El-Mhaidib, "Influence of shearing rate on interfacial friction between sand and steel," Engineering Journal of Qatar University, vol. 19, pp. 1-16, 2006.

[33] T. J. Chen and Y. S. Fang, "Earth pressure due to vibratory compaction," Journal of Geotechnical and Geoenvironmental Engineering, vol. 134, no. 4, pp. 437-444, 2008. 

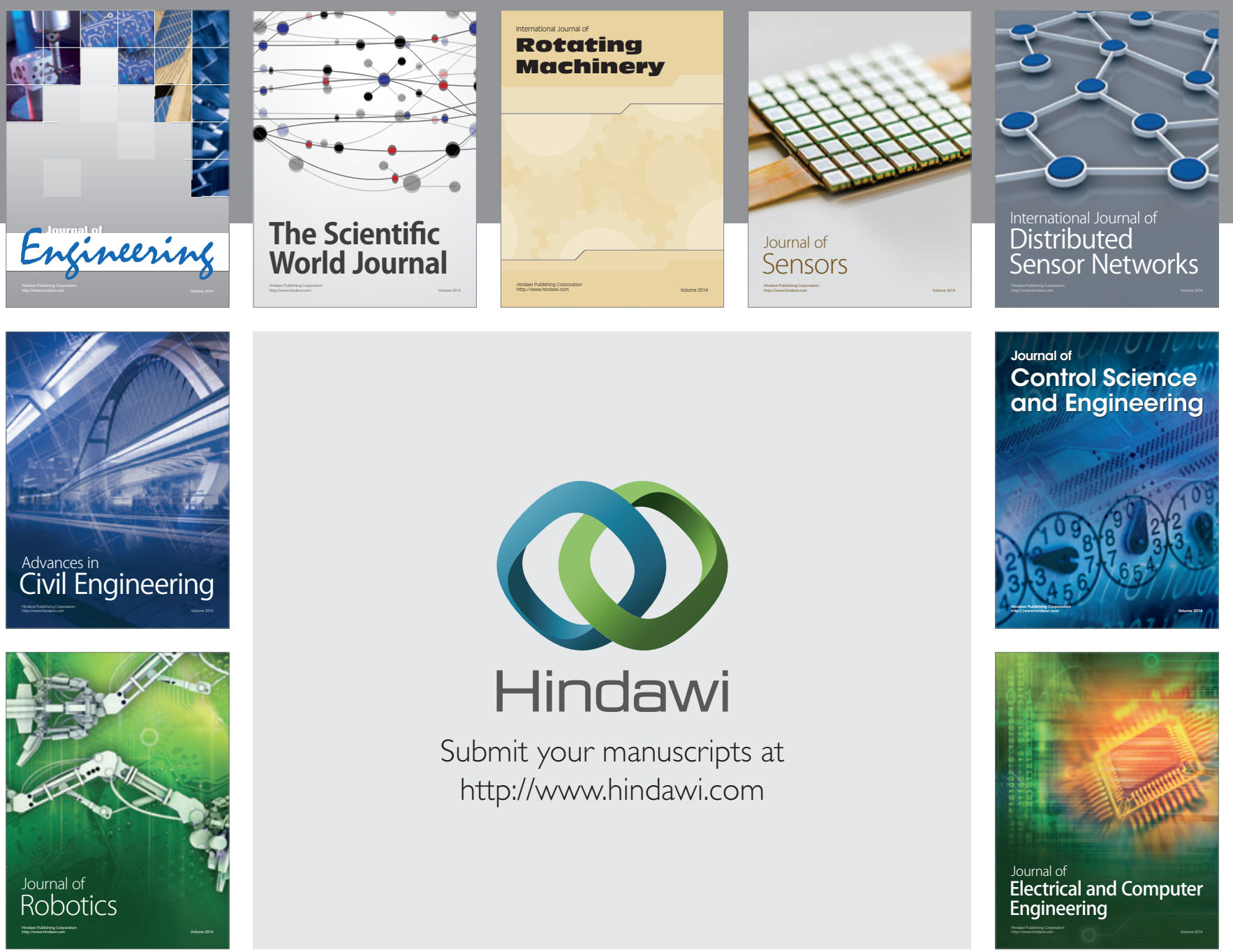

Submit your manuscripts at

http://www.hindawi.com
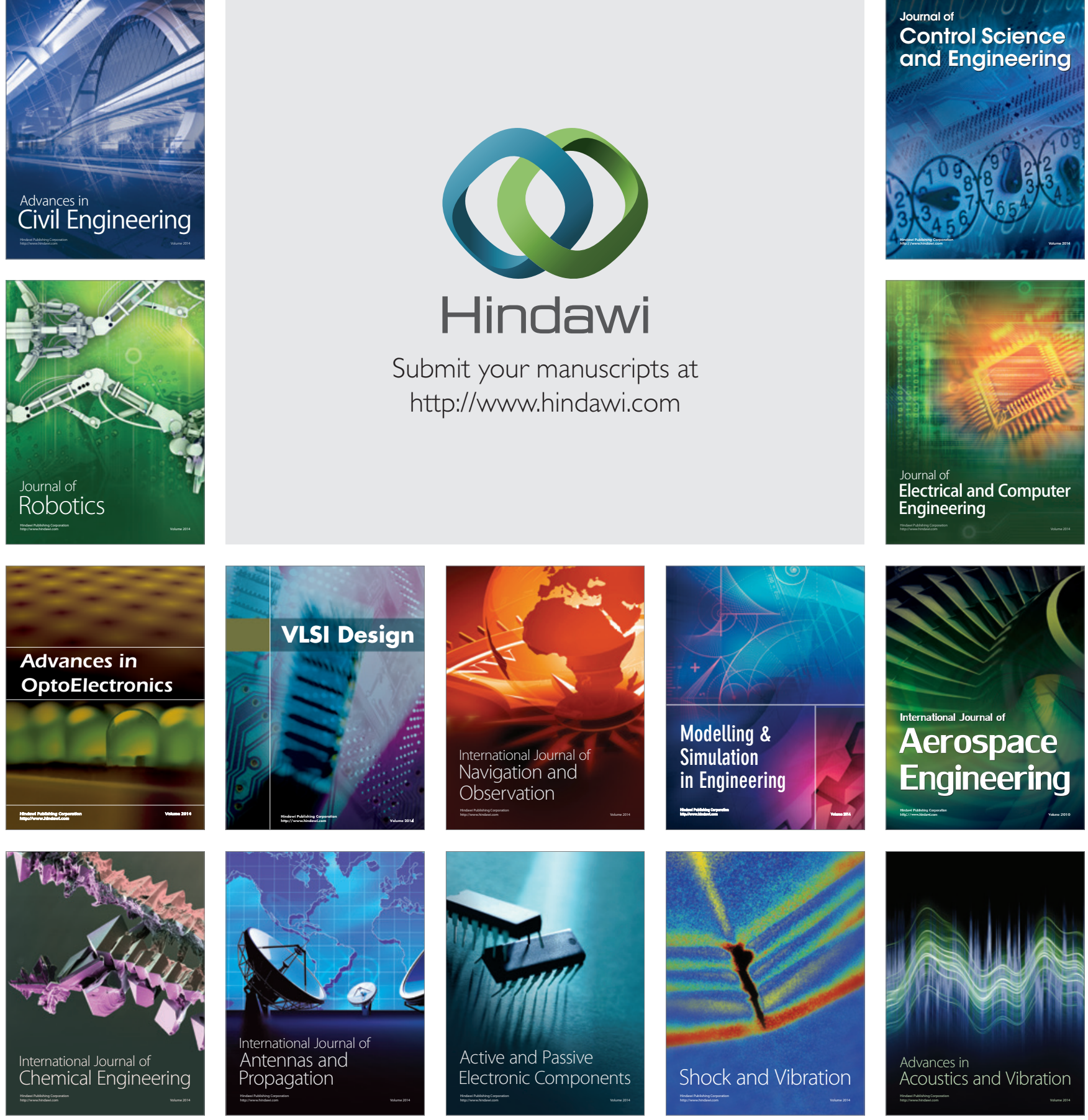